[: : DE92 01575:2

SURFACE ELECTROCHEMICAL CONTROL FOR THE FINE COAL AND PYRITE SEPARATION

DOE Project NO. DE-AC22-89PC89758

Technical Progress Report July 21, 1989--September 30, 1989

\author{
Prepared by \\ Wanxiong Chen \\ Weibai Hu \\ Jyi-Perng Wann \\ Ximeng zhu \\ Milton E. Wadswort.h \\ University of Utah \\ Prepared for \\ U.S. Department of Energy \\ Pittsburgh Energy Technology Center \\ Pittsburgh, Pennsylvania
}

\title{
DISCLAIMER
}

This report was prepared as an account of work sponsored by an agency of the United States Government. Neither the United States Government nor any agericy thereof, nor any of their employees, makes any warranty, express or implied, or assumes any legal liability or responsibility for the accuracy, completeness, or usefulness of any information, apparatus, product, or process disclosed, or represents that its use would not infringe privately owned rights. Reference herein to any specific commercial product, process, or service by trade name, trademark, manufacturer, or otherwise dnes not necessarily constitute or imply its endorsement, recommendation, or favoring by the United States Government or any agency thereof. The views and opinions of authors expressed herein do not necessarily state or reflect those of the United States Government or any agency thereof. 


\author{
SURFACE ELECTROCIIEMICAL CONTROL, FOR \\ FINE COAL AND PYRITE SEPARATION
}

DOE PROJECT NO. DE-AC22-89PC89758

\author{
Technical progress Report \\ $7 / 21 / 89-9 / 30 / 89$
}

This is the first technical progress report prepared in accordance with the reporting requirements of DOE Project No. $D E-A C 22-89 P C 89758$. It will cover only the technical aspects of the work completed from July 21, 1989 to september 30, 1989.

\title{
1. Sample procurement and characterization
}

According to the statement of work, (Task 1: sample procurement and preparation, ) three coal samples which cover a range of sulfur and pyrite content and rank will be selected for study:

(1) Illinois High Volatile c bituminous coal (HVCb)

(2) Pittsburgh High-Volatile A bituminous coal (HVAb)

(3) Upper Freeport Medium Volatile bituminous coal (MVb)

Three coal-pyrite samples will be collected from the above coal seams for study. One typical ore-pyrite sample will be obtained for comparison with the coal pyrite samples.

The samples of the above mentioned three coal seams have been crushed and sampled under an inert atmosphere. The proximate and uitimate analyses of these research samples are shown in Tables 1 and 2 . 
Table 1. Froximate Analysis of Three coal Samples

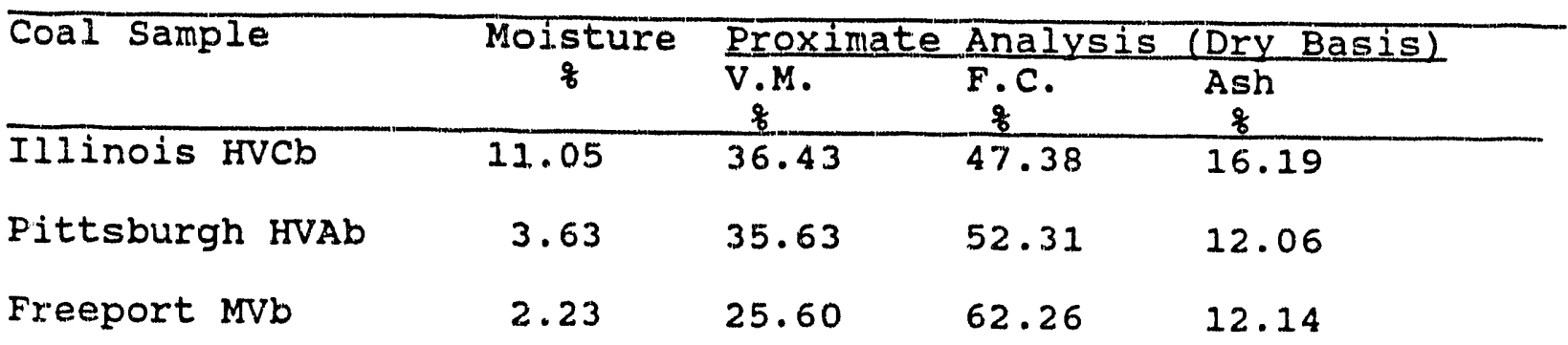

Table 2 Ultimate Analysis and Heat Value of Three coal samples

\begin{tabular}{llllllll}
\hline Coal sample & C\% & Ho & No & S\% & O\% & $\begin{array}{c}\text { Heating Value } \\
\text { Btu/Lb }\end{array}$ \\
\hline Illinois HVCb & 66.48 & 4.56 & 1.12 & 5.19 & 6.46 & 11,814 \\
Pittsburgh HVCb & 72.06 & 4.85 & 1.32 & 3.95 & 5.76 & 12,815 \\
Upper Freeport MVb & 77.25 & 4.64 & 1.32 & 2.24 & 2.41 & 13,601
\end{tabular}

In addition to the three coal-pyrite samples of the above three coal seams, there are also some lump coal-pyrite samples which have been obtained from the Cumberland, Pittsburgh No.8 seam. A coal-pyrite sample from Upper Freeport is relatively difficult to obiain since this coal contains very little disseminated pyrite. Contact was made with PETC, DOE who supplied about 40 small pieces of coal-pyrite from the Upper Freeport coal bed, coshocton County, ohio. Coal-pyrite samples of the IlIinois No. 6 seam will be prepared by hand picking, gravity tabling and superpanning.

Fine sized liberated coal-pyrite samples from the bulk coal samples will be prepared by gravity separation, mainly by shaking table and super panner technology. The sink float method may be unsuitable for our purpose, since the surface of the fine coalpyrite sample very likely will be contaminated by the heavy iiquid. Sink-float separation will be attempted initially on the 
Illinois $\mathrm{H}-\mathrm{V}-\mathrm{C}$ coal first, since it contains the greatest amount of sulfur (5.19\%). The mineral-pyrite samples were obtained from Ward's Natural Science Establishments.

\section{Equipment and Instrument Preparation}

For the electrochemical studiea, the following equipment has been ordered:

(1) Model 378-3/286 electrochemical impedance system, which includes:

1. Model 273 potentiostat/Galvanostat.

2. Model 5208 EC lock-in analyzer.

3. IBM System/2 model 30-286 with IEEE-488.

4. Software: Model 378.

(2) Software: Model 342 .

(3) Model 616 Rotating electrode system.

Using this equipment, several types of routine electrochemical measurements, such as, potentiodynamic polarization, potentiostatic, galvanic corrosion, galvanostatic, cyclic voltammetry, open circuit potential vs time-----etc, can be performed.

Using the entire Model 378-3/286 electrochemical impedance system, studies will be carried out to characterize the formation, growth kinetics and properties of pyrite surface product layers formed, as oxidation proceeds under a broad range of conditions. The properties of the product layer play an important role in the flotation behavior of pyrite.

For the Electrochemical Flotation study, an electrochemicalmicroflotation cell has been designed and is currently being constructed. Figure 1 presents a schematic diagram of the electrochemical-microflotation cell.

A coiled platinum wire lead (A), entering and resting on the ground glass frit (B), serves as the electrical connection to the mineral. bed. A platinum wire, housed in a fine fritted tube (H), serves as the counter electrode, and the tube itself serves as a plunger to compact the mineral particles to ensure physical and therefore electrical contact throughout the bed. pulp potential and $\mathrm{pH}$ will be measured using a combination ORP electrode and a combination $\mathrm{pH}$ electrode in the electrode cell (G) at the same time. Parts $C$ and $D$ respectively served as the inlet and outlet for electrolyte circulation.

For flotation tests, the counter electrode plunger will be raised until the fritted tube (H) is above the center tube but 


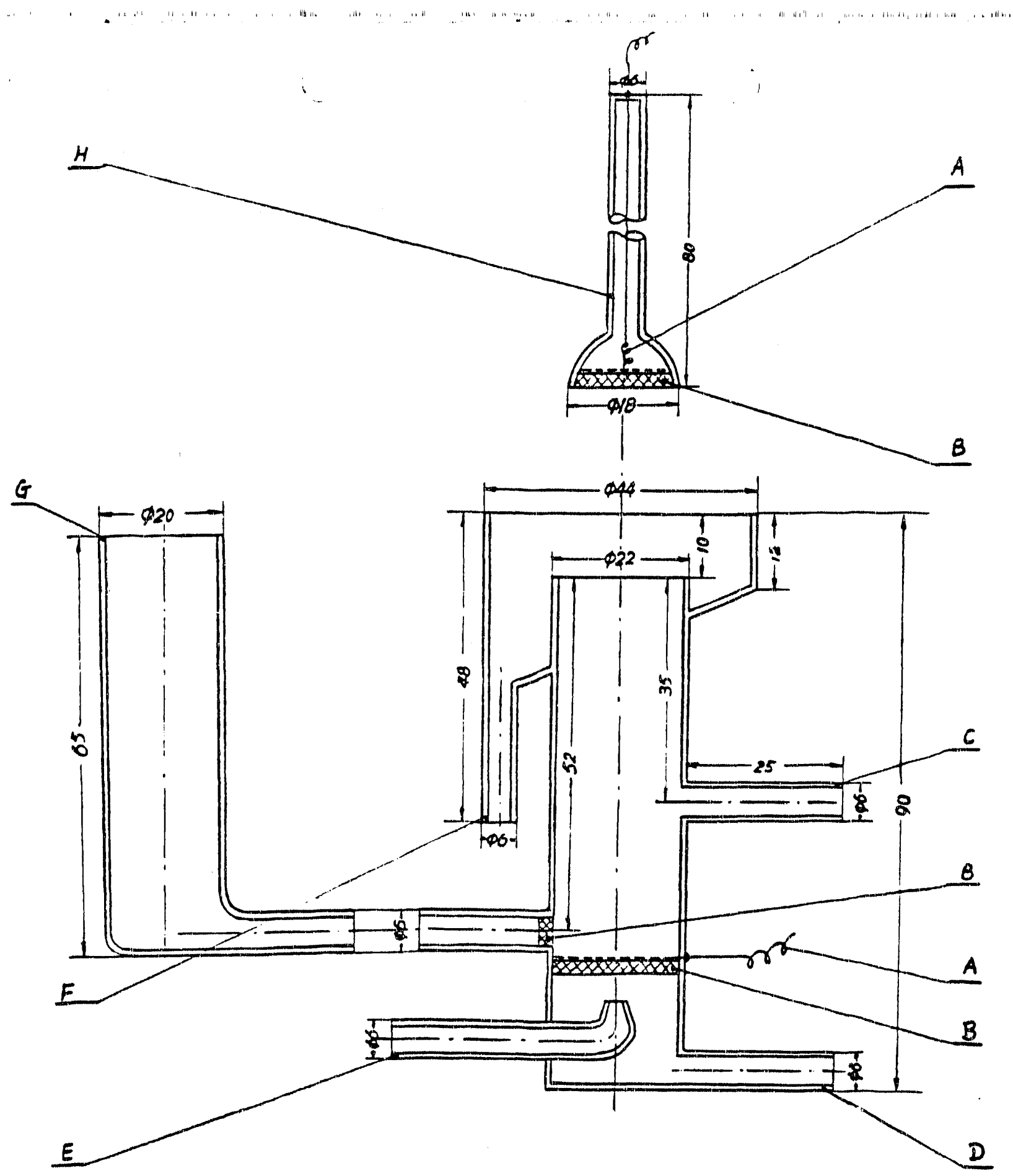

Figure 1: Electrochemical-microflotation cell

$\begin{array}{ll}\text { A: } & \text { Platinum Electrode and Lead } \\ \text { B: Glass Frit } \\ \text { C: } \\ \text { D: Electrolyte Inlet } \\ \text { E: } \quad \text { Nitrogen Inlet } \\ \text { F: } \quad \text { Concentrate Collection } \\ \text { G: } \quad \text { Electrode Cell. } \\ \text { H: } \quad \text { Counter Electrode Compartment }\end{array}$


still making electrical contact with the electrolyte. In this configuration, nitrogen entering through port $\mathrm{E}$ is bubbled through the frit and mineral bed, and any particles levitated by the bubbles will be deflected by the counter electrode compartment (H) and deposited around the outside of the center tube. For the standard Flotation rest, a labolatory flotation machine designed after that of the department $0:$ Energy (PETC) will be used.

\section{Preliminary Electrochemical Measurements of selected ore- Pyrite and coal-pyrite samples.}

\subsection{Experimental materials and procedures:}

Electrode: A mineral-pyrite electrode and a coal-pyrite electrode were prepared from pieces of natural crystals. The mineral-pyrite was a collection sample from ward's National Science Establishment and the coal-pyrite was a sulfur refuse sample obtained from cumberland, $\mathrm{PGH}$, No. 8 Seam, Greene county, PA. Its $\mathrm{FeS}_{2}$ content was $>75 \%$. These pyrite samples were cut to size and encapsulated in epoxy. The exposed surface area of the samples was $1 \times 1 \mathrm{~cm}^{2}$ and polishing was carried out by sequentially using $1.0,0.3$, and 0.05 micron $\mathrm{Al}_{2} \mathrm{O}_{3}$ before each measurement.

Solution: Three solutions of various $\mathrm{pH}$ were used

$$
\begin{array}{llll}
\mathrm{pH} & 7.99 & 0.025 \mathrm{M} \mathrm{Na}{ }_{2} \mathrm{~B}_{4} \mathrm{O}_{7}+0.1 \mathrm{M} \mathrm{HCl} \\
\mathrm{pH} & 9.10 & 0.010 \mathrm{M} \mathrm{Na} \mathrm{B}_{4} \mathrm{O}_{7} \\
\mathrm{pH} & 10.39 & 0.025 \mathrm{M} \mathrm{Na} \mathrm{B}_{4} \mathrm{O}_{7}+0.1 \mathrm{M} \mathrm{NaOH}
\end{array}
$$

$\mathrm{Na}_{2} \mathrm{SO}$ was added to the above solutions to bring total ionic strength to $0.5 \mathrm{M}$.

Equipment and procedure: Polarization measurements were conducted at room temperature in a three-compartment pyrex cell. Both the saturated calomel reference electrode and the graphite counter electrode were kept in separate compartments of the cell. The solucion in the working electrode compartment was stirred magnetically, and was deoxygenated by bubbling argon for about one hour before inserting the sample electrode into the cell. The flow of argon at the surface of the solution was continued during each electrochemical measurement to eliminate diffusion of atmospheric oxygen into the cell. Data were taken by an EG\&G M173 Potentiostat programmed with an IBM PC-XT computer. The scanning rate for polarization measurements was $0.5 \mathrm{mv} / \mathrm{sec}$.

Because the electrode surface was very easily oxidized during polishing, the initial open-circuit potentials in deaerated solutions were not reproducible. But after conditioning the electrode at a reducing potential (-150mv or - 
$200 \mathrm{mv}$ ) for a few minutes, the open-circuit potentials were almost stable. Thus all the electrochemical measurements in this report were started after the following procedure: polishing the electrode->conditioning the electrode at a reducing potential - > waiting until a relatively stable opencircuit potential was reached.

\subsection{Experimental results:}

The open-circuit potentials of mineral-pyrite and coalpyrite electordes in solutions of various $\mathrm{pH}$ are listed in following table:

Table 3. Open Circuit Potentials

Sample

mineral-pyrite

coal-pyrite open-circuit potential (mv.vs S.C.E.)

pH $7.99 \quad \mathrm{pH} 9.10 \quad \mathrm{pH} 10.39$

-30 to $-35 \quad-110$ to -115

$-150$

-30 to $-35 \quad-80$ to $-85 \quad-120$

The open-circuit potentials of both mineral-pyrite and coalpyrite decreased with increasing solution $\mathrm{pH}$ and the open-circuit. potentials of mineral pyrite were about $30 \mathrm{mv}$ lower than those of coal pyrite, except in the solution of $\mathrm{pH} 7.99$.

The anodic and cathodic polarization curves of mineralpyrite and coal-pyrite in solutions of various pH are illustrated in Figs. 2, 3 and 4 . It was obviously that in lower potential region, the coal-pyrite was more active than mineral-pyrite.

The effect of solution $\mathrm{pH}$ on the anodic polarization of mineral-pyrite and coal-pyrite is illustrated in Figs. 5 and 6. For both mineral-pyrite and coal-pyrite, the anodic oxidation was $\mathrm{pH}$ dependent and the current increased with increasing $\mathrm{pH}$ at constant potential.

From the data shown in Figs 5 and 6 , log current at constant potential vs $\mathrm{pH}$ and potential (at constant current) vs pH plots were made. These are shown in Figs. 7 and 8 for mineral-pyrite and Figs 9 and 10 for coal-pyrite. The average slopes of the curves in Figs. 7 and 9 corresponded to an order of 0.78 and 0.36 with respect to $\mathrm{pH}$ ( $\log 1 /$ unit $\mathrm{pH}$ ) for mineral-pyrite and coal-pyrite respectively, and the average slopes of the curves in Figs. 8 and 10 corresponded to an order of -83 and -72 with respect to $\mathrm{pH}$ (mv/unit $\mathrm{pH}$ ) for mineral-pyrite and coal-pyrite respectively. Both results indicated consistently that the mineral-pyrite oxidation reaction was more $\mathrm{pH}$ dependent than coal-pyrite.

The anodic and cathodic polarization curves of mineral- 
pyrite and coal-pyrite, scanning in the forward direction and then reversed are shown in Figs. 11, 12,13 and 14 . In each case, the curve of reversed scan shifted appreciably from that of forward scan. The rest potentials increased after anodic polarization and decreased after cathodic polarization for both the mineral-pyrite and coal-pyrite. These results indicate that the anodic and cathodic reactjons are not reversible. The extent of irreversibility was more significant in case of the coal-pyrite.

After anodic polarization a yellow to reddish brown film on electrode surface was observed. These films were more obvious when solutions of higher $\mathrm{pH}$ was used. It, is likely that iron oxide films formed during anodic oxidation are variable in oxidation state and coherence depending upon $\mathrm{pH}$ and the rate of formation. These films will be characterized in future studies. 


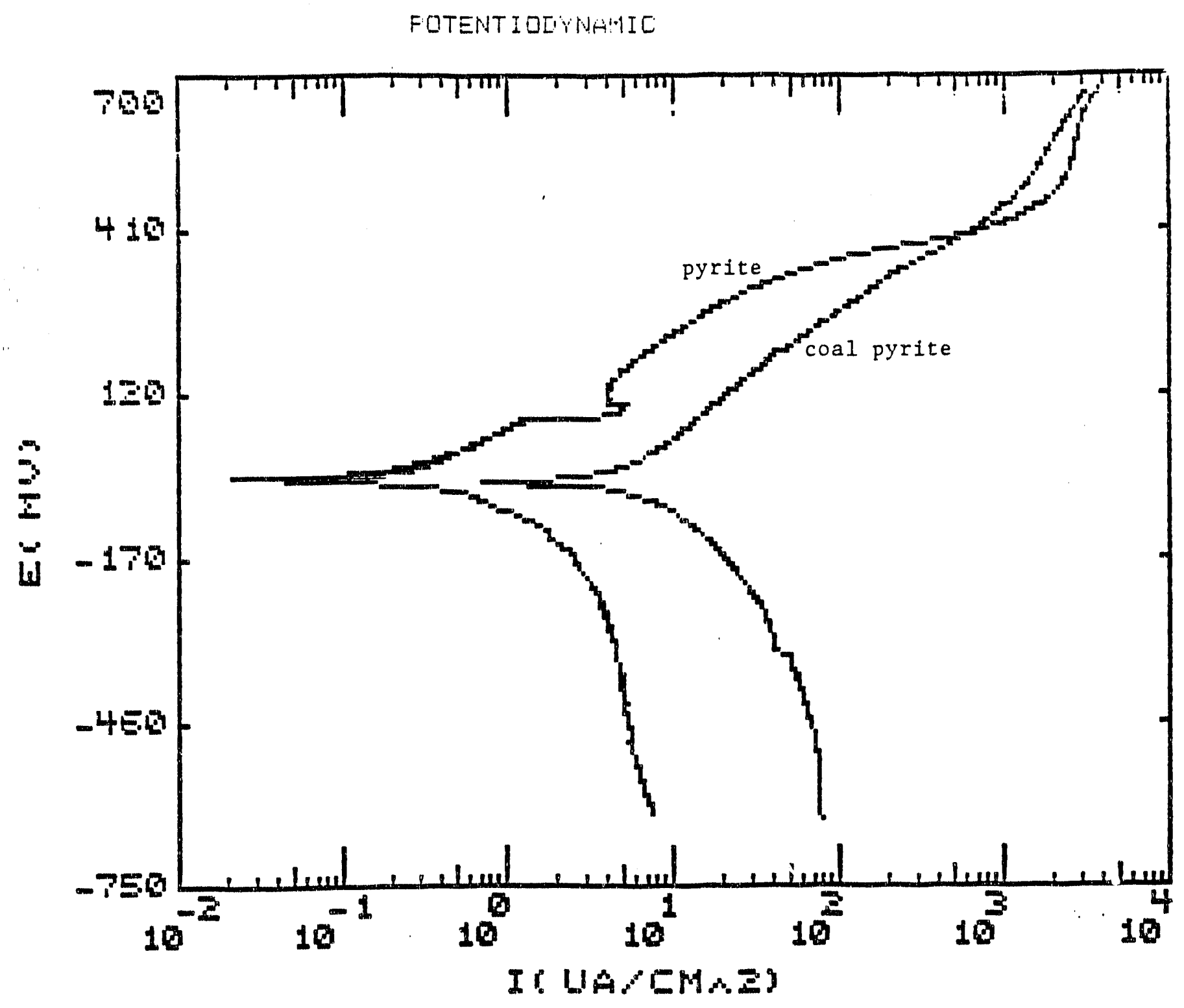

SOLUTION $\mathrm{pH} 7.99$

Fig. 2 


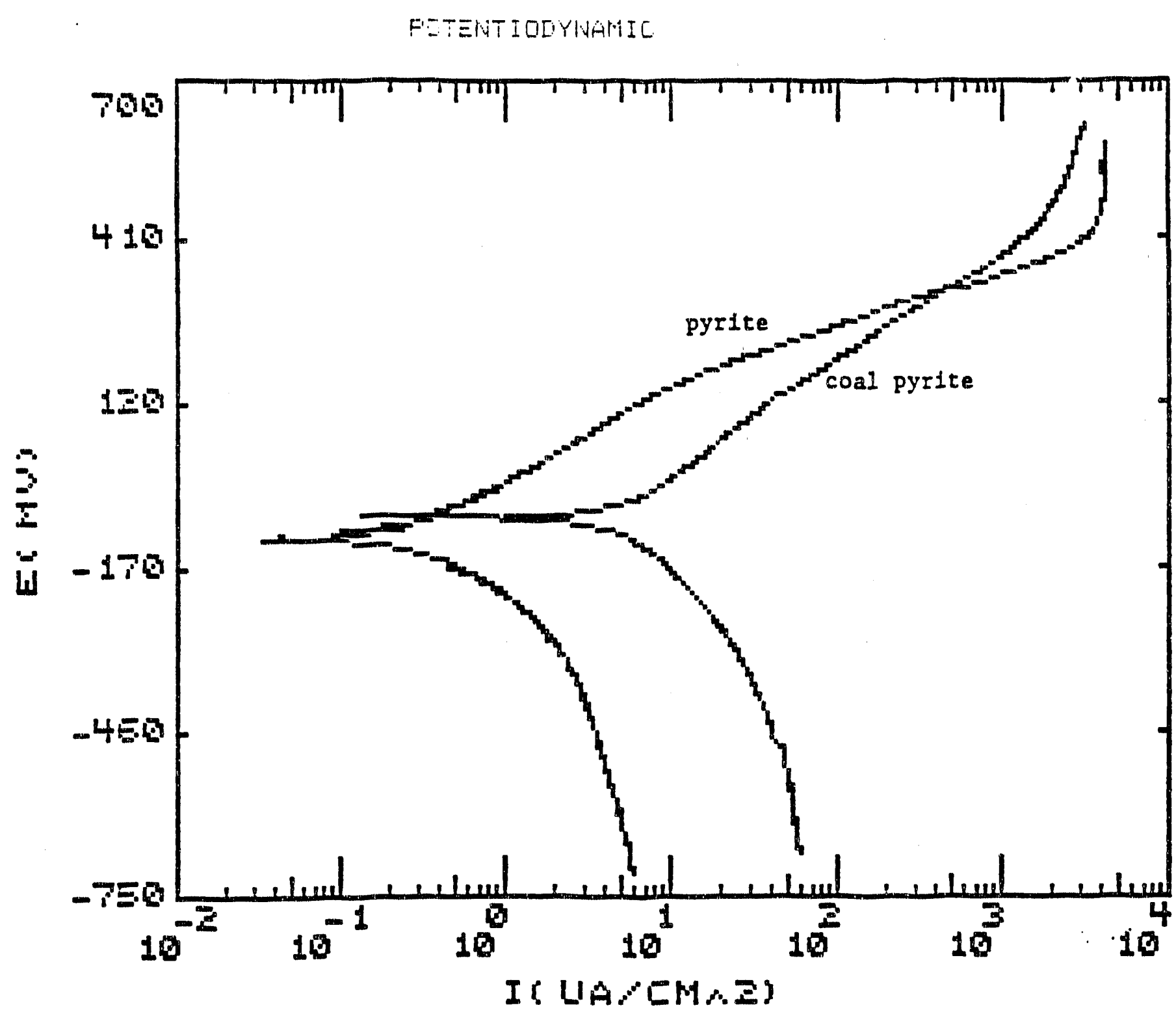

SOLUTION PH 9.10

F18. 3 


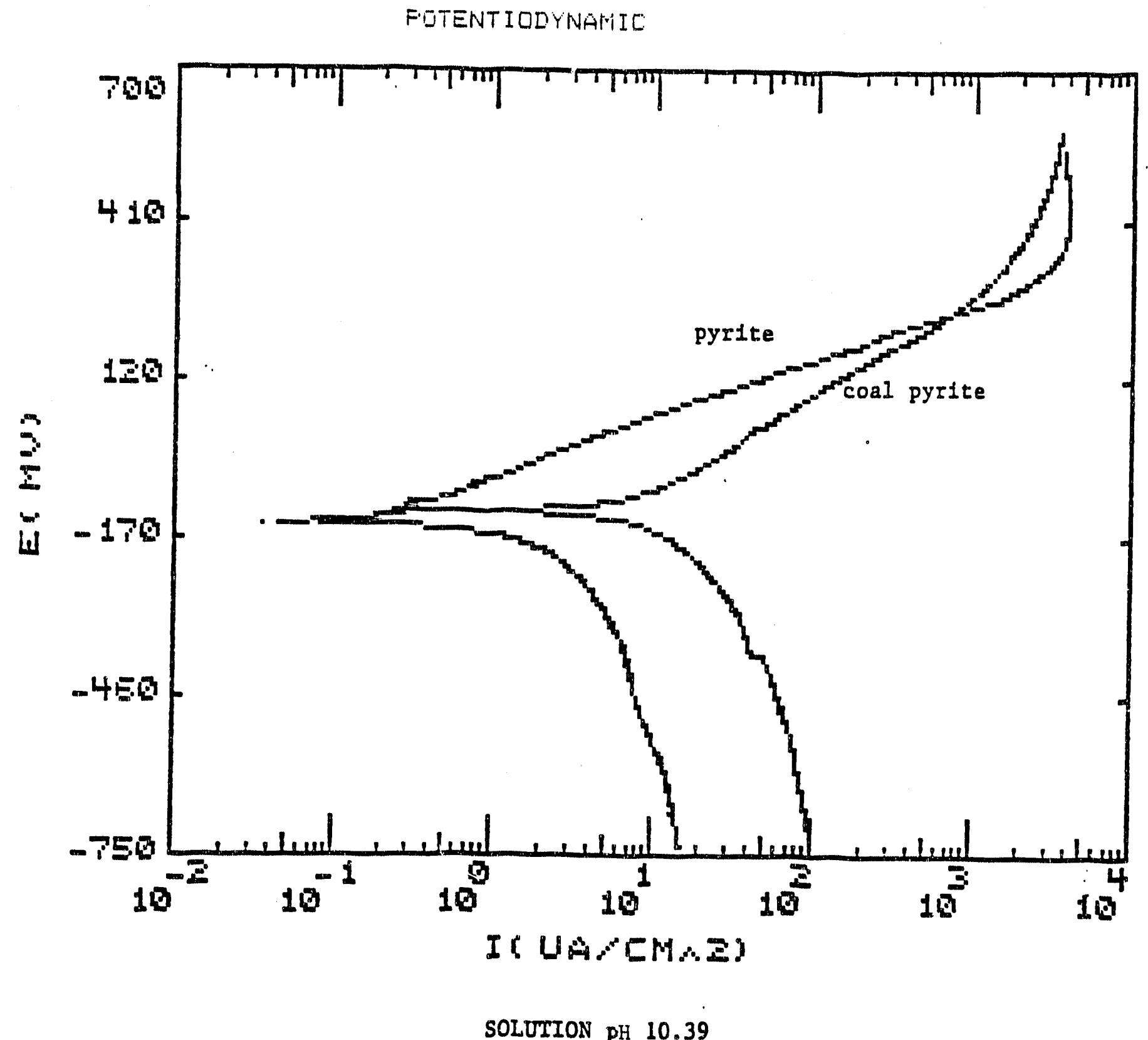

FIg. 4 


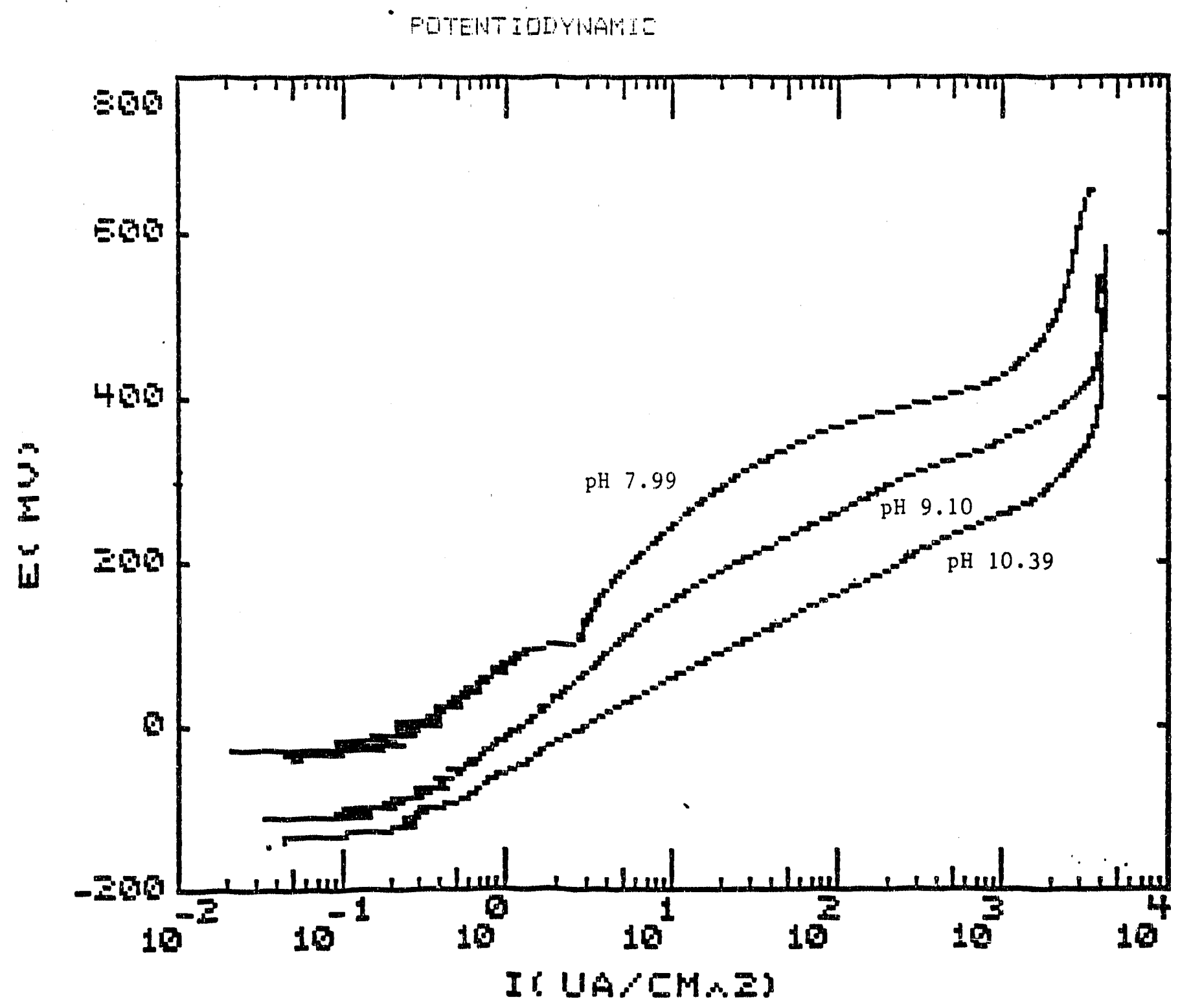

ANODIC POLARIZATION OF MINERAL PIRITE

F1g. 5 


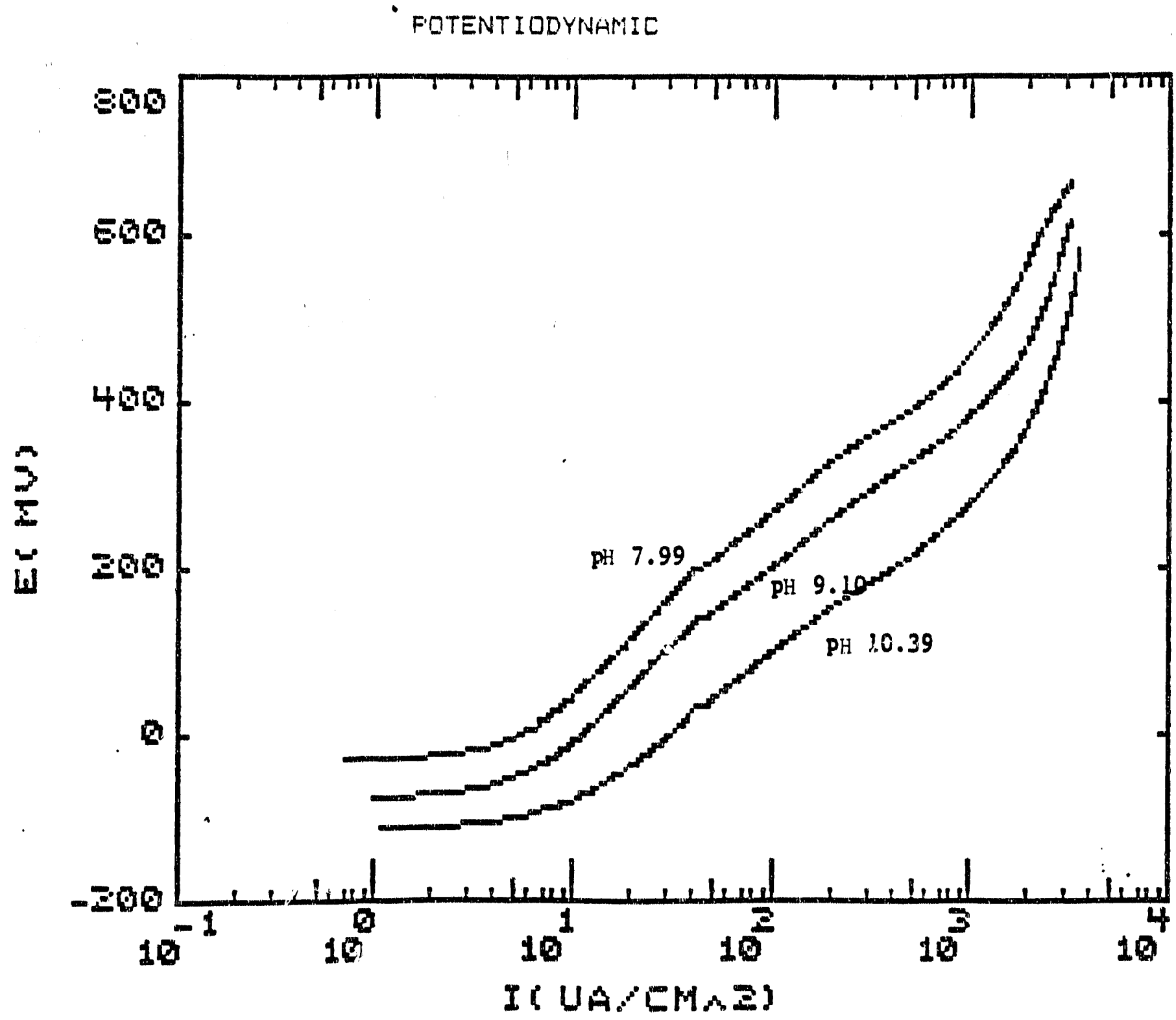

ANODIC POLARIZATION OF COAL PYRITE

PIg. 6 


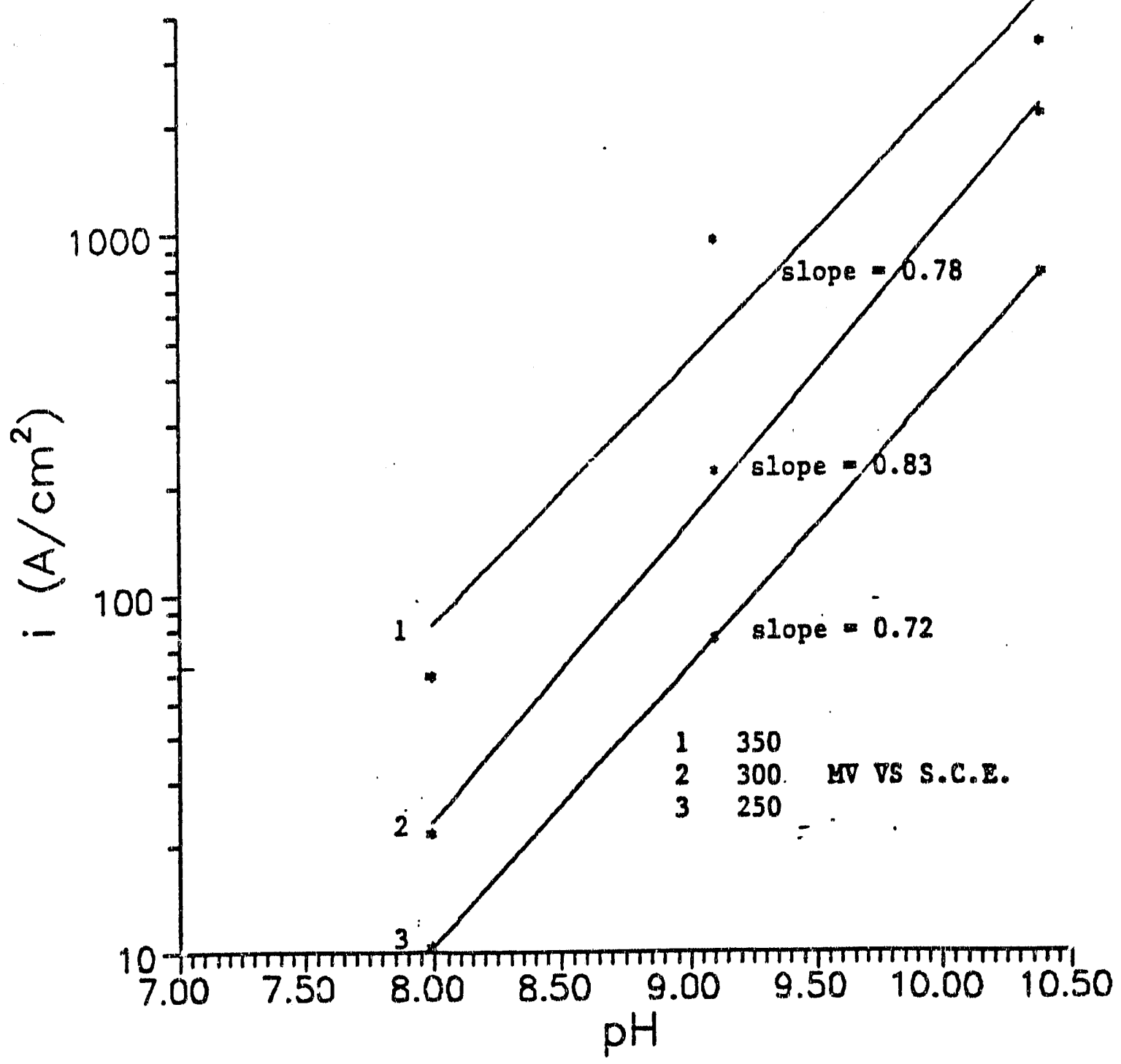

DEPENDANCE OF CURRENT DENSITY OF MINERAL PYRITE ON PH AT VARIOUS ELECTRODE POTENTIALS. 


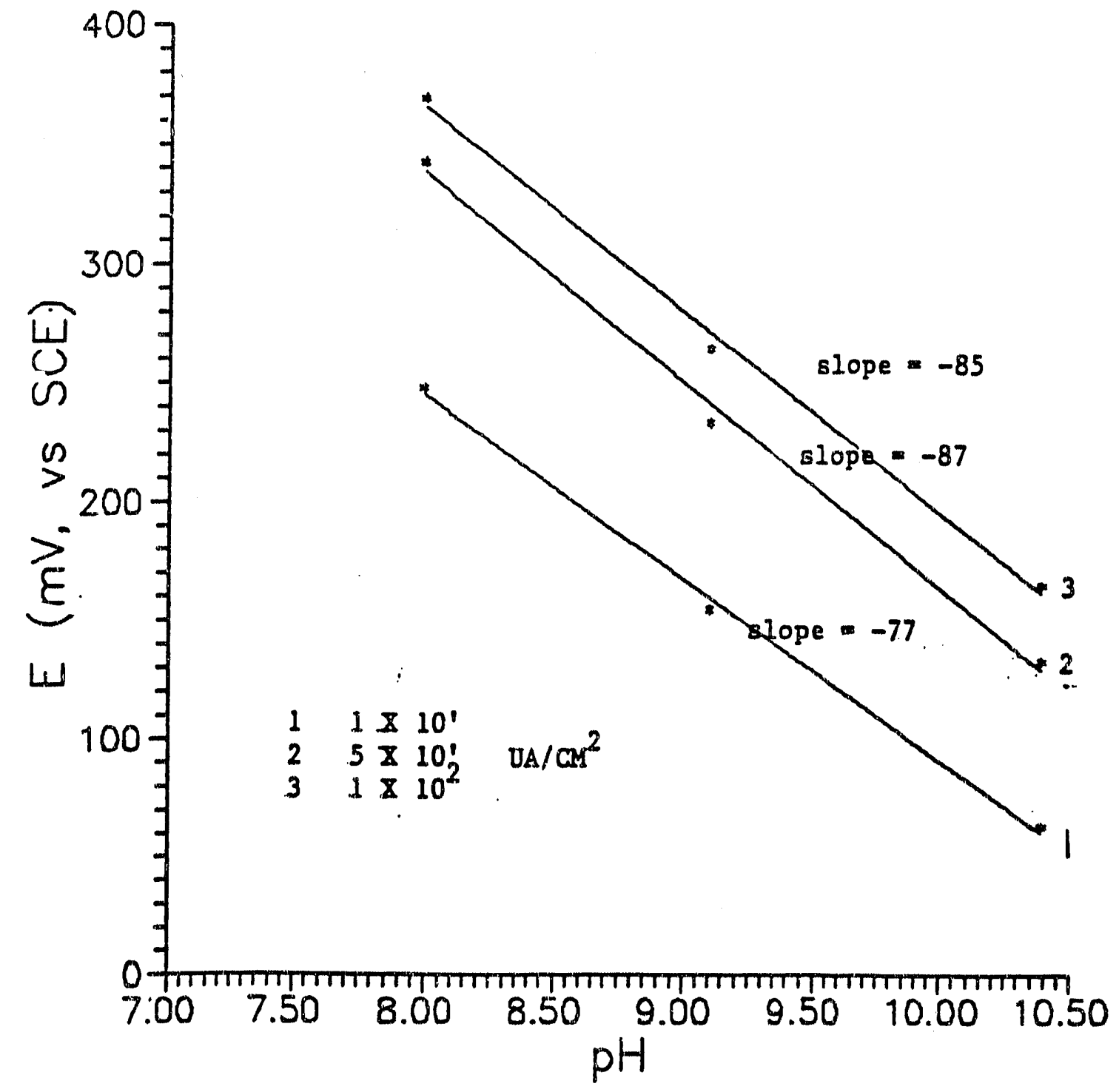

DEPENDANCE OF ELECTRODE POTENTIAI, OF MINERAI PYRITE ON PH AT VARTOUS CURRENT DENSITIES.

PIg. 8 


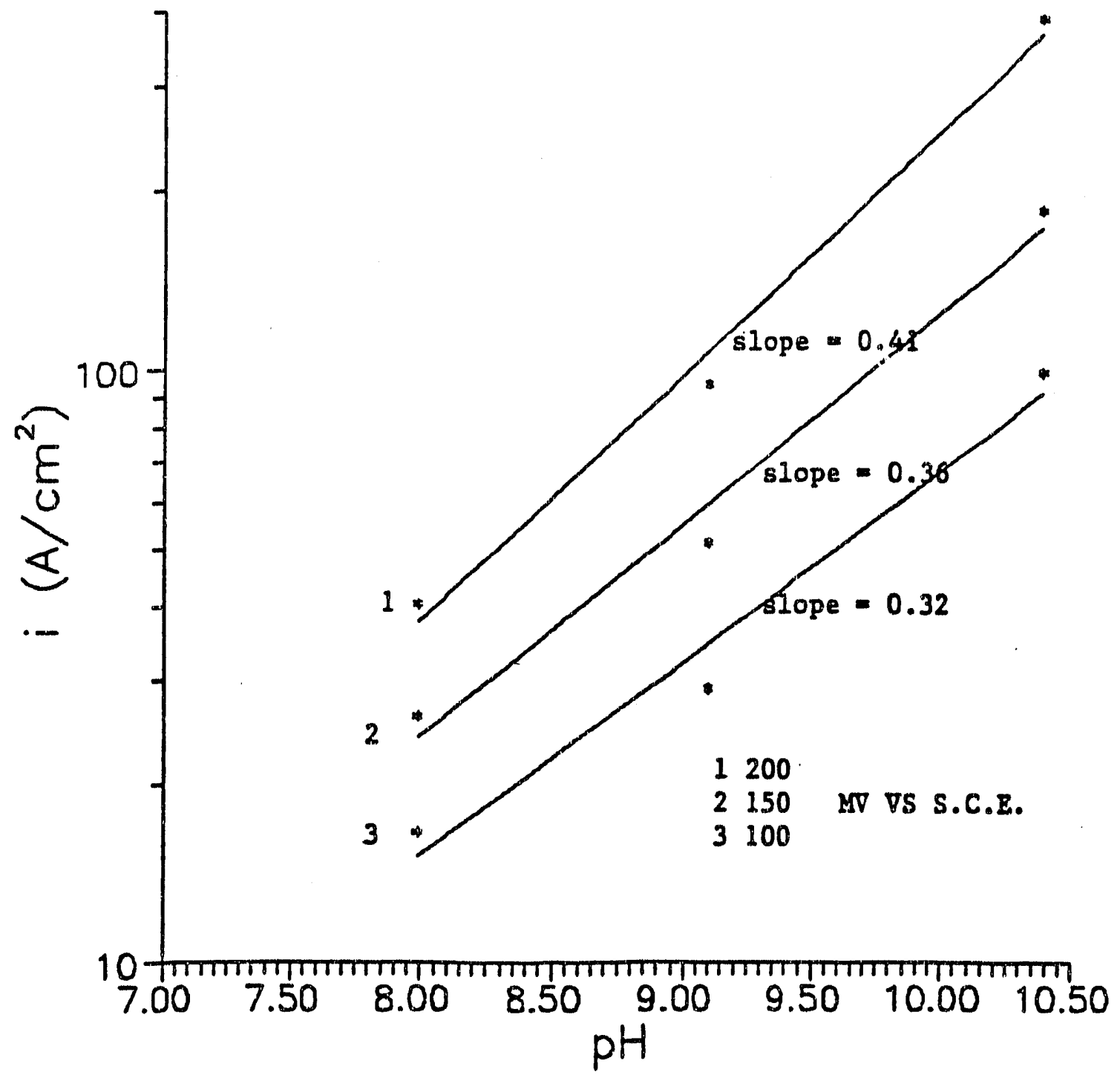

DEPENDANCE OF CURRENT DENSITY OF COAL PYRITE ON

PH AT VARIOUS ELECTRODE POTENTIALS.

Pig. 9 . 


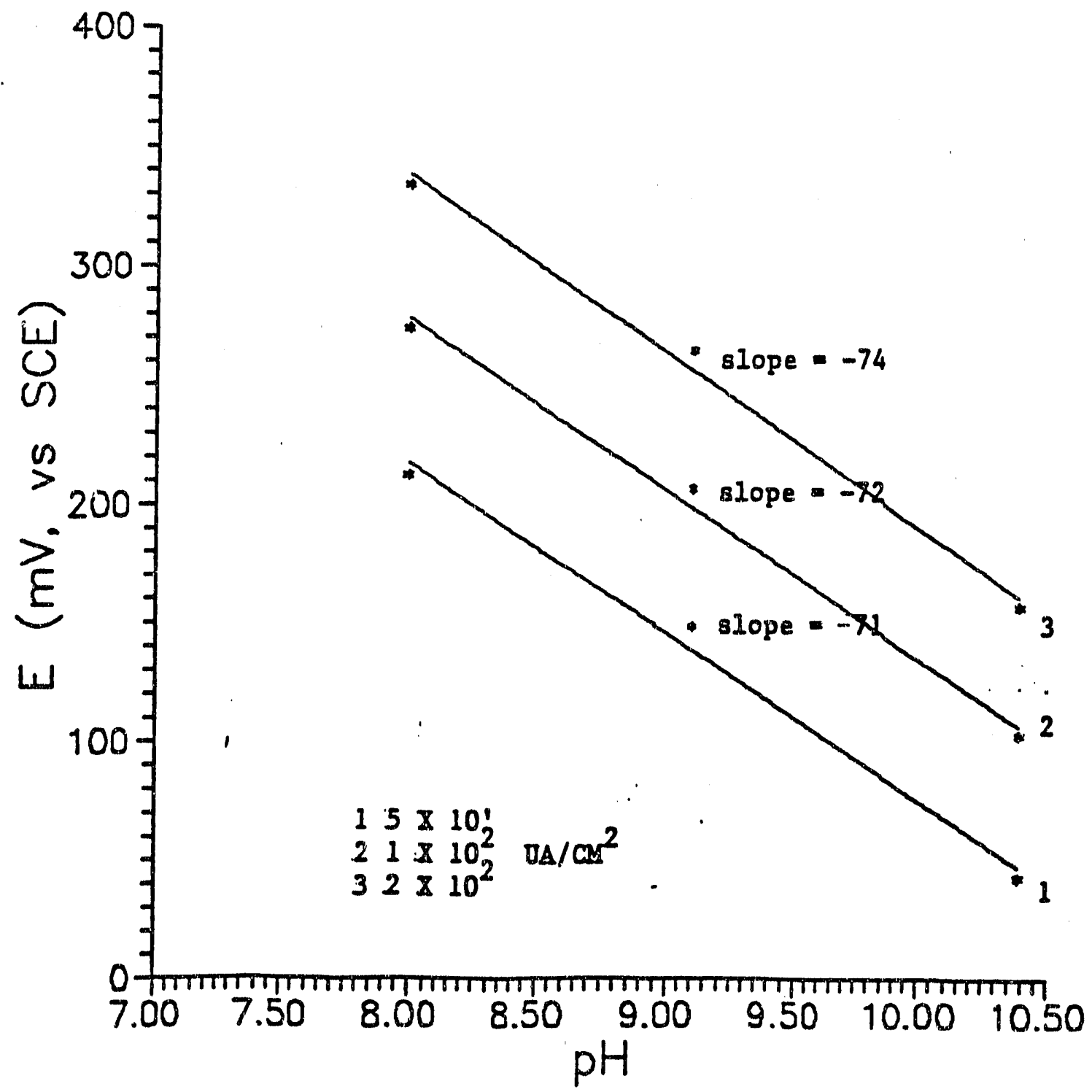

DEPENDANCE OF ELECTRODE POTENTIAL OF COAL PYRITE ON

PH AT VARTOUS CURRENI DENSITIES.

P18. 10 


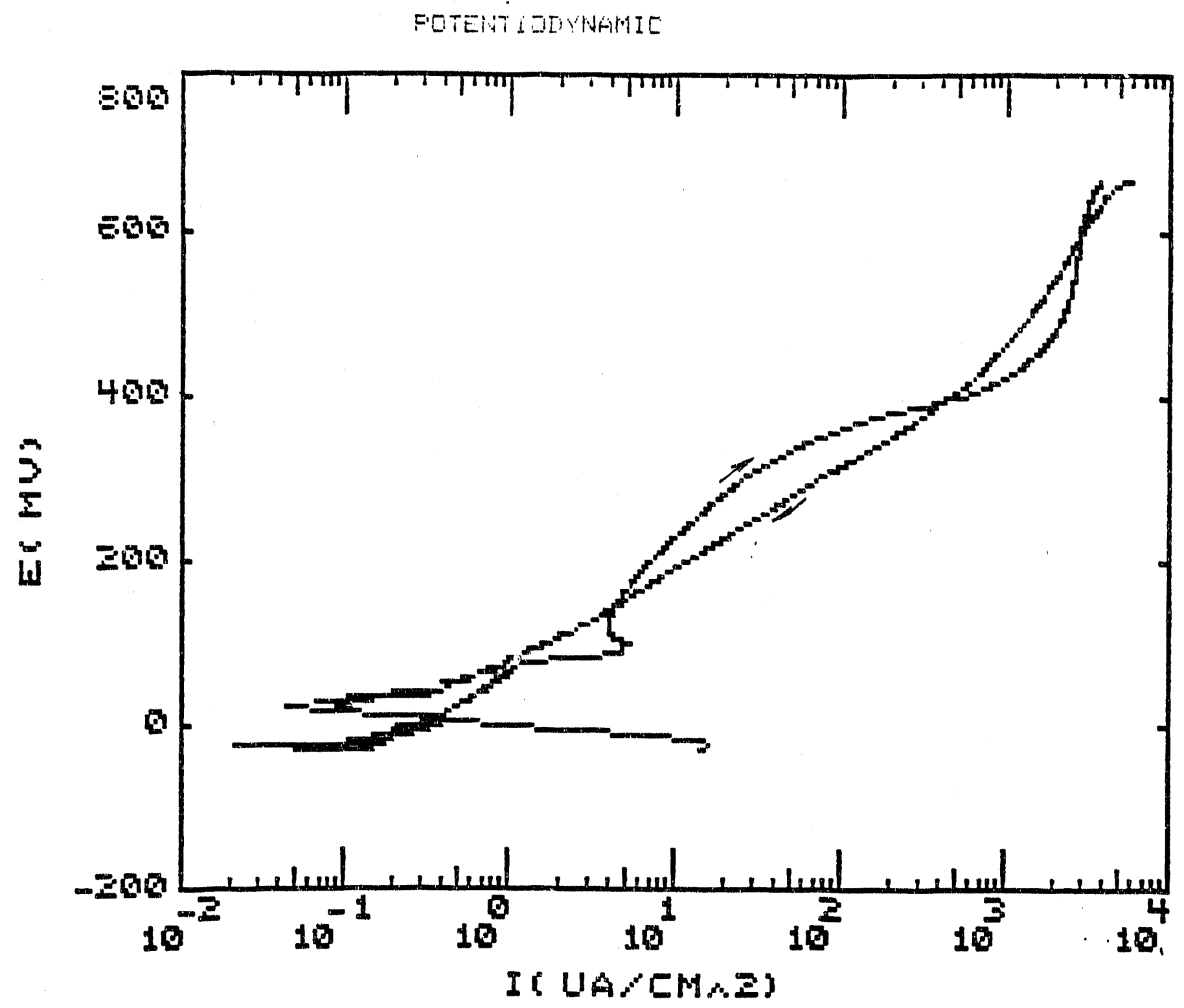

ANODIC POLARIZATION OF MINERAL PYRITE

SCANNING FORWARD AND BACKWARD.

SÓLUTION PH 7.99

PIg. 11 


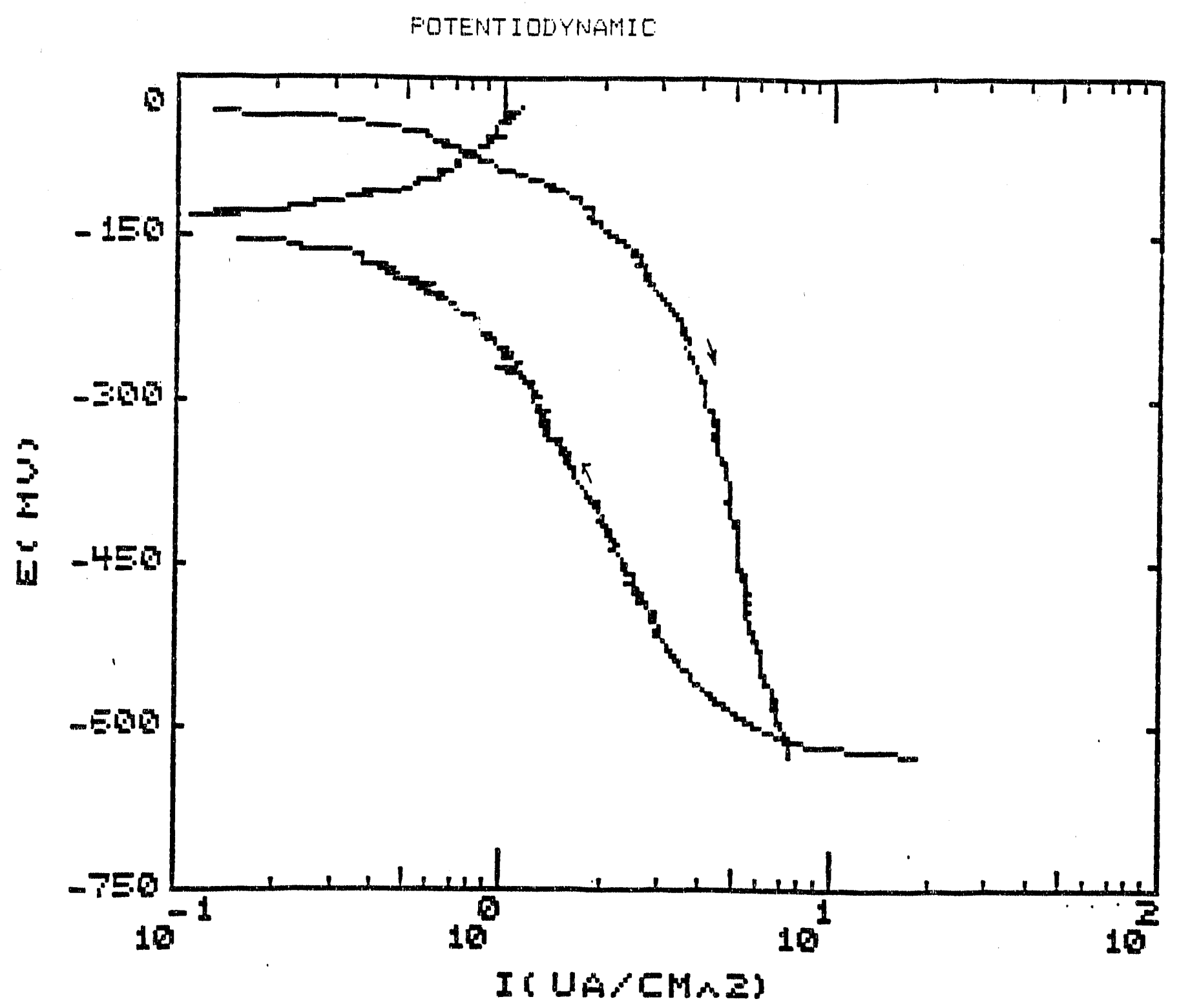

CATHODIC POLARIZATION OF MINERAL PYRITE

SCANNING FORWARD AND BACKWARD

$\because \quad$ SOLUTION PḦ 7.99

F1g. 12 


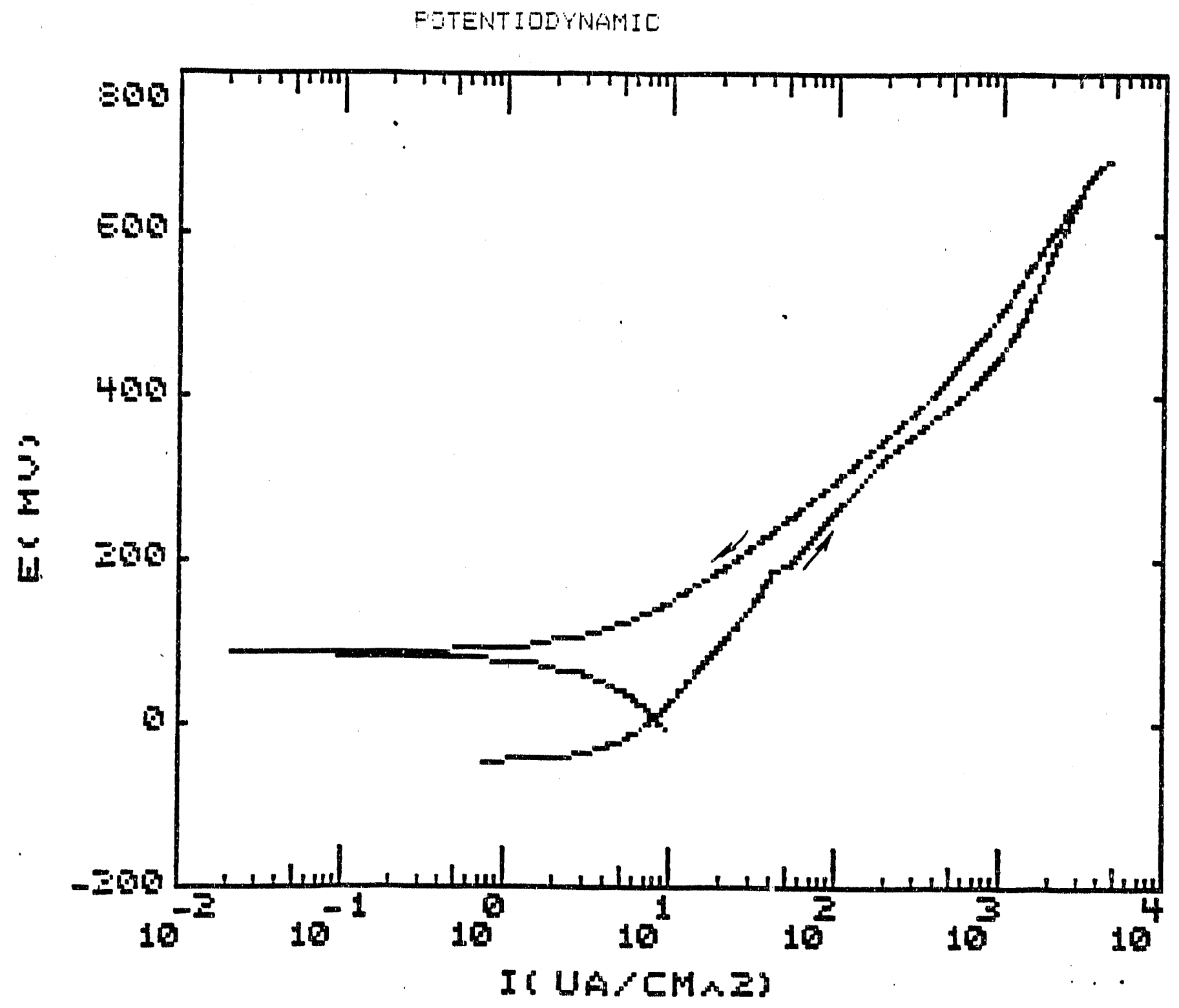

ANODIC POLARIZATION OF COAI PYRITE

SCANNING FORWARD AND BACKWARD

SOLUTION PH 7.99

F1g. 13 


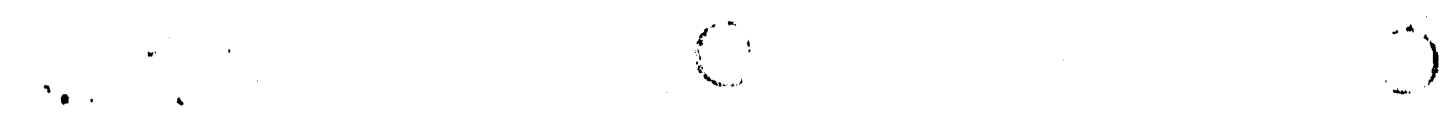

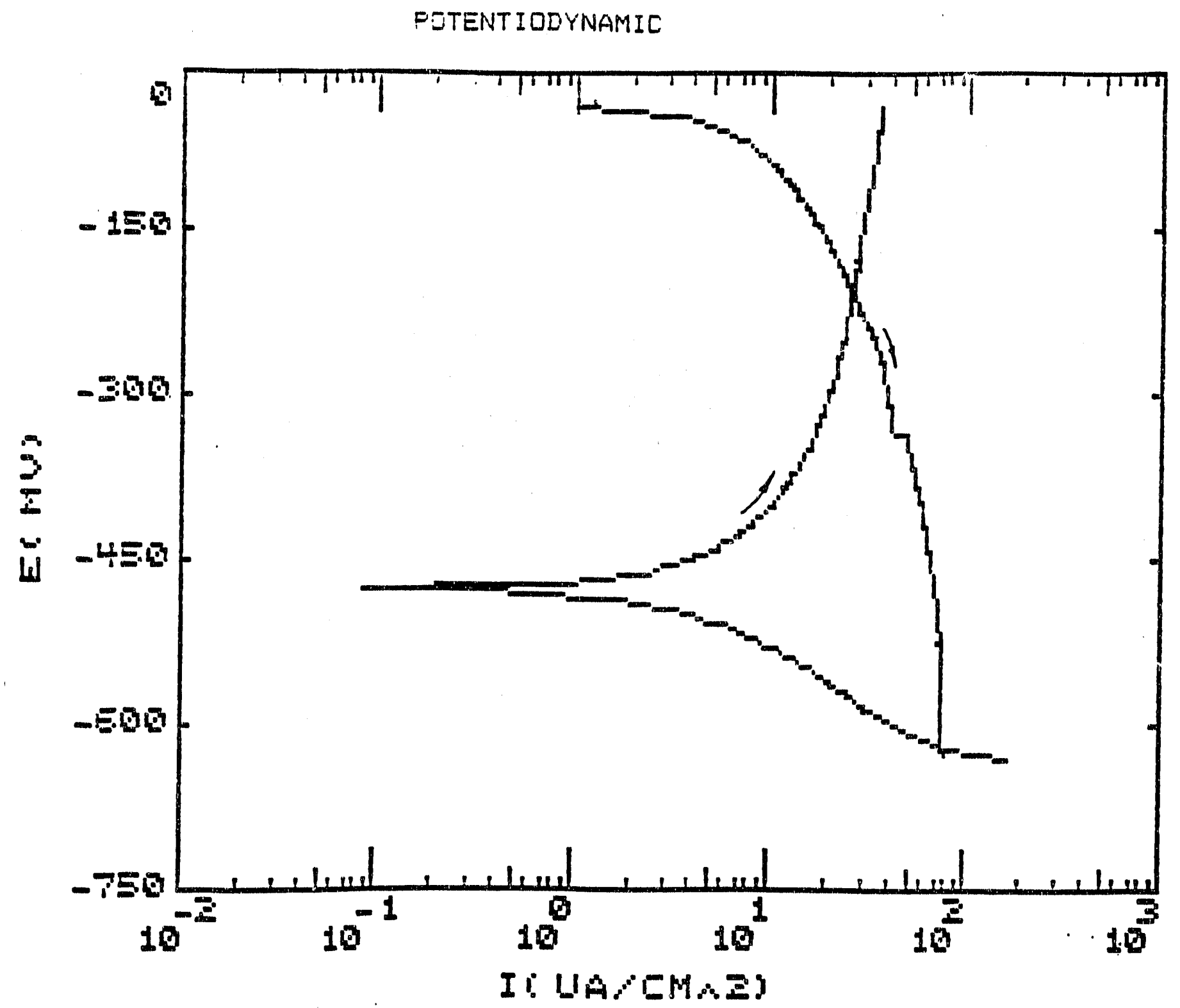

CATHODIC POLARIZATION OF COAL PYRITE

SCANNING FORHARD AND BACKWARD

SOLUTION PH 7.99

P18. 14 


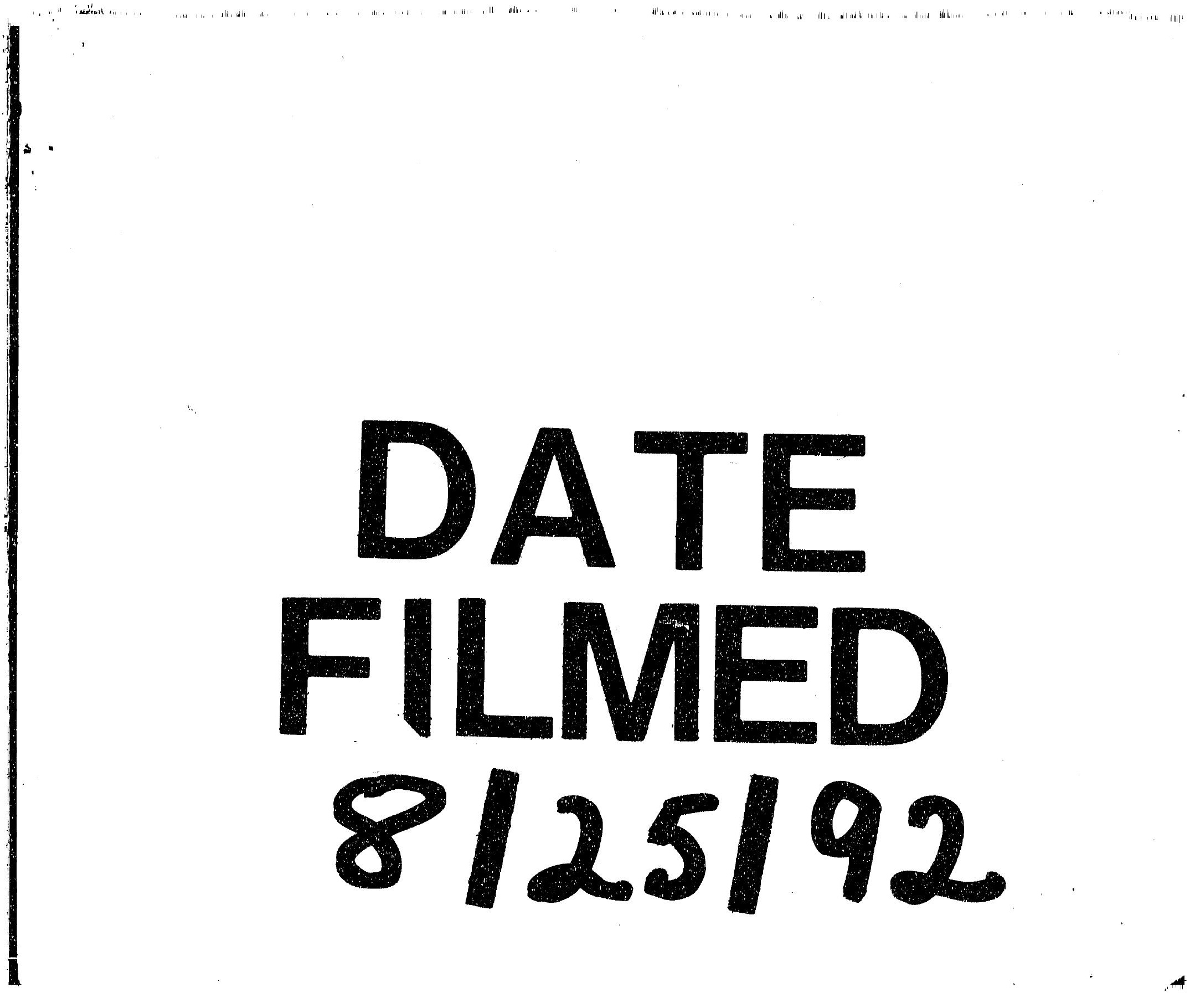


